\title{
段波津波に粘り強く抵抗する 被覆ブロック式防潮是の提案
}

\author{
松島健一 ${ }^{1} \cdot$ 毛利栄征 $^{2} \cdot$ 大串和紀 $^{3} \cdot$ 川邊翔平 ${ }^{4} \cdot$ 龍岡文夫 $^{5}$
}

\begin{abstract}
無補強盛土をブロックで被覆した従来式防潮堤は, 高潮などに対して質量の大きなブロックと透水性の高い栗 石を組み合わせることで, 波力への抵抗力と揚圧力の軽減を同時に図っている . しかし，津波のような段波に 対しては，堤防内部に持続的な動水圧が伝播することでブロックおよび栗石層が押し流されたり，越流時に生 じる揚力によってブロックが引き剥がれたりする可能性がある . これらの構造的課題を解消するため, 難透水 性のセメント改良土とブロックをジオテキスタイルで一体化し，さらにブロック同士を連結した新型式防潮堤 を提案する . 水理実験結果から, 新型式防潮堤は揚圧力によるブロックの剥離と堤体内部への動水圧の伝播を 遮断することにより，高い安定性を確保できることが分かった . また , 裏法肩付近に発生する揚力に対しても ジオテキスタイルでブロックを盛土と一体化することで, 引き剥がれに対抗できることが分かった .
\end{abstract}

キーワード : 段波津波 , 防潮堤 , ジオテキスタイル , プレキャストブロック , セメント改良土

1.はじめに

従来式の被覆ブロック式堤防は, ブロック重量をもつ て波力に対抗し，開口部を有するブロックと栗石を組み 合わせることて積極的に透水・透気性を高めて揚圧力や 残留水圧の発生を低減している.このような透水・透気 構造は波浪のように比較的周期の短い波に対しては有効 であるが , 周期が長い段波に対しては動水圧が一方向に 継続して作用するので , 表法ブロックの隙間を通じて堤 防内部の透水層に津波が流れ込み，天端コンクリートや 裏法ブロック背面に強い揚圧力か発生する可能性がある . これまで被覆ブロックの力学的安定性 (例えば，堀川， 1991，JCE，1998) は，主に流水や波浪力㳔象とされ， 継続的に波力が作用する段波に対しては検討されていな い. また近年補強土を用いた防潮是か数多く提案されて いるが (例えば，山口ら，2014，常田ら，2014) ，衝突 波力時や津波越流時等における各種部材の挙動や堤防内 部の構造に関して十分なデータか蓄積されていない．

乥こで, 本研究では, 東日本大震災における津波およ ひ堤防の損傷特性等を明らかにするとともに，堤防高さ を上回る段波を対象にした水理実験を行い，従来の被覆 ブロック式堤防の構造的課題を確忍し，より有効な対策 法を目指して被覆ブロック及び炎の背面の盛土構造を改 良する方法を検討した 。

\section{(1) 津波の入射特性}

同一の津波高さであっても , 湾の形状や地形条件に よって樣々な波高 , 周期の津波力出現する . 例えば , 図

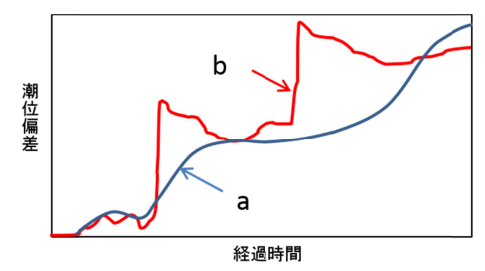

图1 さまざまな゙津波波形

一1に示すようにaの津波波形では海面か穏やかに上昇し， 静水圧に近い波圧力湜防に作用するが，bの段波を含む 津波波形の場合は静水圧を大きく上回る水圧力圷是防に作 用する傾向にある .

图一几上岩手県野田市十府ヶ浦て撮影された津波現象を 示している. 図2 2(a) に第1線堤の防潮是と，第2線堤の 国道の位置関係を示す . 図-2 b) は , 津波衝突時の映像 である.巨大な水柱力出現していることから，高流速の 段波力発生していたことが伺える. 図-2 ( c)は第1線堤の 損傷状況であり，壊烕的な被害を生じていた。一方，第 1線堤から陸側に $100 \mathrm{~m} \sim 300 \mathrm{~m}$ 離れた第 2 線堤 $(\mathrm{TP}+7.8 \mathrm{~m})$ は, 津波痕跡高さから推定7.0m以上の大規模な越流力生 じたものの，図-2(d)\&(e)に示すように表法及び裏法と も軽微な損傷に留まっていた .このことから，第1線堤 を含屯前浜間て段波が大きく減勢され，堤防への損傷が 軽減された可能性力指摘できる。

以上のことから，第1線堤の防潮堤の安定性の検討 には，単に津波高さだけではなく，海岸地区ごとに特徵 が異なる津波の入射特性 (段波特性) を考慮することが 重要であると言える .

\footnotetext{
1,4正会員, 農研機構 農村工学研究所 († 305-8609 茨城県つくば市観音台2-1-6)，2正会員, 茨城大学 農学部, 教授 (下 300-0393茨城県 稲敷郡阿見町中央3-21-1 )，3正会員，(株) 竹中土木 常務執行役員 (广 136-8570 東京都江東区新砂1-1-1 ), 5正会員,東京理科大学理工 学部, 教授 (广278-8510千葉県野田市山崎2641)
} 
(2) 段波津波の衝突波力

段波津波によって堤防に作用する衝突波力は，段波の 砕波状態によって大きく異なる.沖側で発生した段波が 浅瀬に到達すると, 波高力高くなる. 乥して, 水深に比 べて波高が高くなると，低い位置の波よりも高い位置の 波が早く進むので, やがて波頂か前方に落ち込む．本研 究では, このような砕波現象を明確に区別するため，堤 防に衝突する際の波の形態を，以下の3つに区別した .

(a)非砕波吅砕波しないまま堤防に到達する波

(b)沖砕波吅堤防よりも沖側て砕波した波

(c) 直前砕波吅 堤防直前て砕波する波

図-3にこれら 3 種類の砕波状態での代表的な波圧分布 を示す. 進行波高に対する波力係数 (静水圧に対する比 率) は, (a) 非砕波の場合で0.8倍程度を示した . (b) 沖砕 波の場合では 3.0程度となっており，朝倉ら(2011)の沖砕 波時の波力係数とほぼ同じ值を示した .これらの波力は いずれも作用時間は長い．これに対して，(c) 直前砕波 は, 作用時間は10msec程度と極めて短いが, 波力係数は 5〜20倍程度と極めて大きい．

\section{2 ．実験方法}

本実験では，堤防高さを上回る規模の段波を再現する ためゲート開放式の段波発生装置を用いた .なお，レベ ル2津波発生時における段波の規模は海岸地区毎に異な るので, 実験との対応関係は個別に検討する必要がある .

\section{(1) 実験装置}

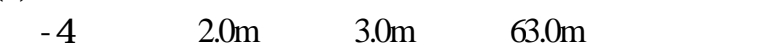
一ト引き上げ装置を有する大型二次元断面水路を使用し た . 沖側の水路に設置したゲート上流に貯水することで 初期水位との水位差を設け, ゲートを一気に引き上げる ことで, 周期20秒程度 (現地換算て約80秒) の段波を発 生させた . 堤防模型は水路床から $1 / 60$ 勾配の斜面を取付 け，高さ0.63mの水平地盤面上に設置した . 波高および 流速は容量式波高計およびプロペラ式流速計を用いて， 堤防前浜部H1および, 堤防天端中央部H2の 2 ヶ所て計 測した . 流速計は初期水面から高さ $5.0 \mathrm{~cm}$, 堤頂から高 さ5.0cmの位置に乥れ設置した . 波圧は小型圧力セ ンサーを用いて計40個の位置て計測した . 計測間融は衝 撃的な゙波力を計測するため，1.0msecに設定した（水 谷・今村，2000）. 堤防の損傷過程については, 高速力 メラによって観察した .なお, 本模型実験ではフルード の相似則に従うものと仮定した .

\section{(2)堤防モデル}

模型堤防は，現地換算で高さ $6.0 \mathrm{~m}$ ，天端 幅4.0mの緩勾配( 表法1.0: 2.0 , 裏法1.0: 2.0) と した . 模型縮尺は1: 15である . 基礎地盤は 固定床とし，基礎工は完全固定した . 以下 に，従来式堤防モデルと新形式堤防モデル を説明する。

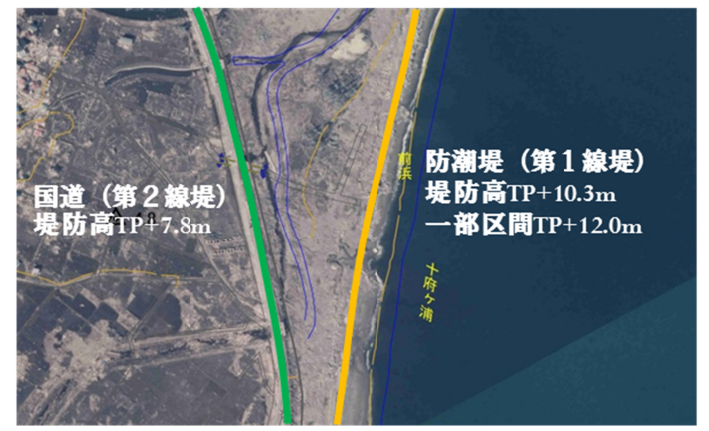

（a）第 1 線堤および第 2 線堤の位置図（国土地理院）
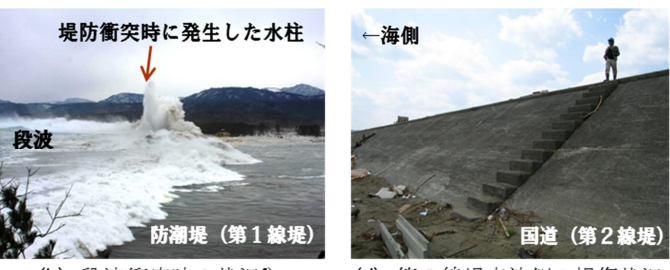

(b) 段波衝突時の状況5)

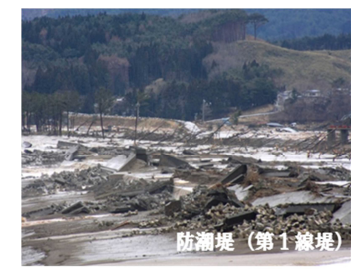

（d）第 2 線堤表法側の損傷状況

(c) 第 1 線堤の損傷状況 5$)$

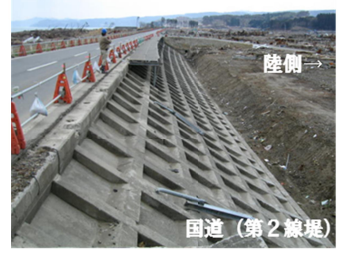

（e）第 2 線堤裏法面の損傷状況

図-2 岩手県野田市十府ヶ浦における被災事例
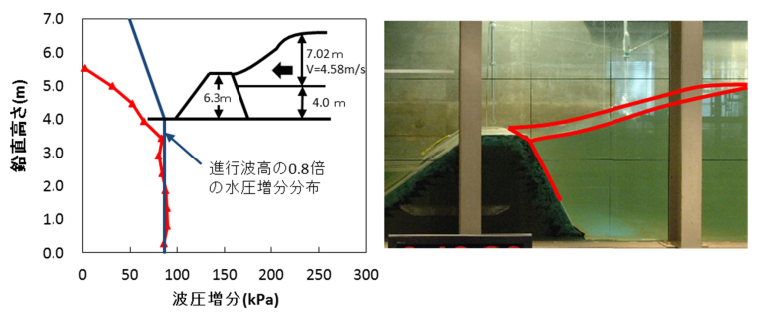

(a) 非砕波型の衝突波圧分布

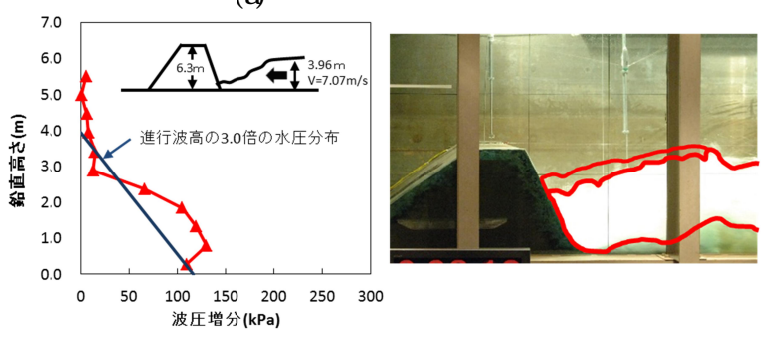

(b) 沖砕波型の衝突波圧分布

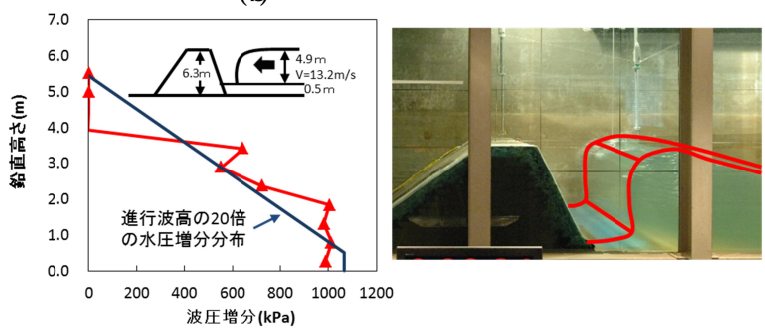

（c）直前砕波型の衝突波圧分布

图-3 段波津波の波力特性

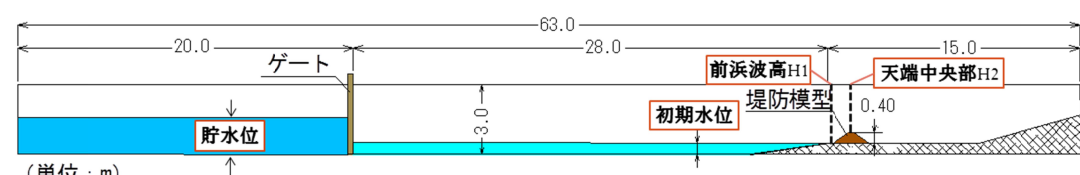

图-4 大型断面二次元水路 (実寸) 
a) 従来式堤防のモデル

図-5に, 本研究て検討した従来式堤防モデルの断面構 造を示す . 表法面側には波浪時に発生する揚圧力を低減 させるため, 開口部を有する被覆ブロックを配置し，裏 法面側には，堤防を乗り越えた越流水を安定的に流下さ せるため，開口部を有さない被覆ブロックを配置した . 被覆ブロックは現地換算で厚さ $0.50 \mathrm{~m}$, 重量約2.0tonであ

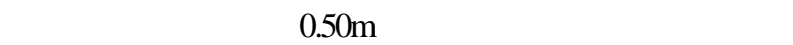
被覆ブロック及び天端コンクリート(以下 , 天端コンと 略称する)の背面には,透水・透気層として厚さ $0.50 \mathrm{~m} の$ 栗石層(粒径 $150 \mathrm{~mm}$, 模型值 : 粒径 $10.0 \mathrm{~mm}$ ) を合成板上に 設置した . 堤防天端コンの内外面には波圧計を配置し, 表面に作用する波圧およひ堤防内の栗石層に作用する水 圧を計測した。

b) 新形式堤防のモデル

段波津波に対抗するために，図一に二示す三面一体化に よる新形式堤防を提案する.ジオテキスタイルを連結し た被覆ブロックと難透水性のセメント改良土によって一 体化した被覆構造を形成した上で, 表法・裏法・天端を 連結した構造となっている。以下に，本堤防によって期 待される効果を示す。

・被覆ブロックをジオテキスタイルによって盛土に固定 することで, 地震力による基礎地盤の沈下や盛土の 変形, 越流による地盤洗掘に伴う裏法尻の浮き上が りと滑動による被覆ブロックのズレや不陸の発生を 防止する。

・開口部を有しないブロックと難透水性のセメント改良 土を組み合わせることで, 堤防内部への津波の侵入 を遮断する . 同時に , 固結力によって吸出しに対す る抵抗力を確保する。

・ブロック同士をジョイント結合させることで, 津波衝 突時の波力に対する滑動抵抗力および揚圧力による 巻き上げに対する抵抗力を確保する .

・法肩ブロックと天端コンを連結し，堤防越流時に裏法 肩付近に発生する負圧による引き剥がれに対抗する． 上記の三面一体化構造を実現するため，図-7に示すよ うにジオテキスタイルを連結したブロック (以下 , ジオ テキブロックと略称する) を新たに開発した . 本実験で は , ジオテキブロックの模型の背面に難透水性のセメン 卜改良土を配置した新型式堤防の実験模型を作成した . 図-8に, 本研究で検討した緩勾配タイプ (1:2.0) および 急勾配タイプ(1: 0.5)のモデルを示す . 被覆ブロックを固 定するジオテキスタイルは, 津波衝突時にブロック背面 に発生する揚圧力や越流時に裏法肩に作用する揚力の大 きさなどに基ついて敷設長や引張強度等を決定する必要 がある.ここでは，松島ら (2014) カ揚力に対抗するた めに必要な引張強度の計算結果を参考にして, 現地換算 で引張強度約 $33.0 \mathrm{kN} / \mathrm{m}$, 長さ $1.0 \mathrm{~m}$, 目合い180 mm× 180 $\mathrm{mm}$ のジオテキスタイルを用いた .なお，模型值では長 さ $66.7 \mathrm{~mm}$, 引張り強度 $2.2 \mathrm{kN} / \mathrm{m}$, 目合い $12.0 \mathrm{~mm} \times 12.0$ mmである. セメント改良土は, 遮水性および流水に対 する耐侵食性を高めることが重要になる.このため，セ

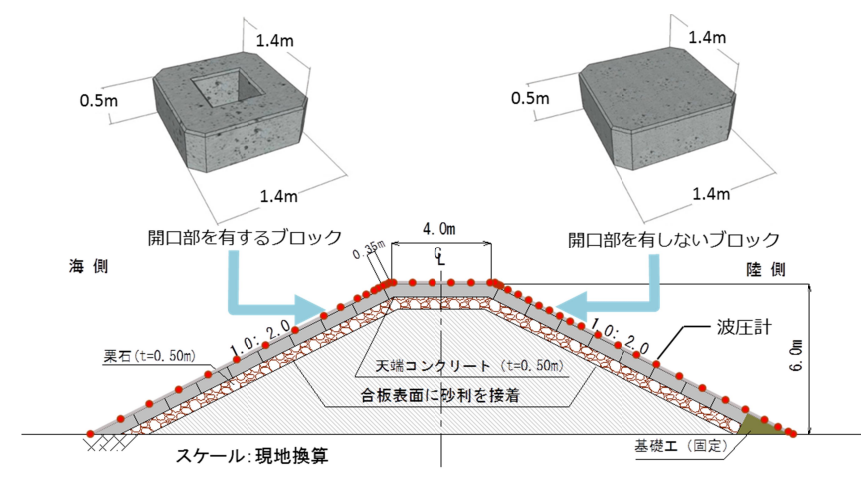

図 5 従来式堤防のモデル (Model01)

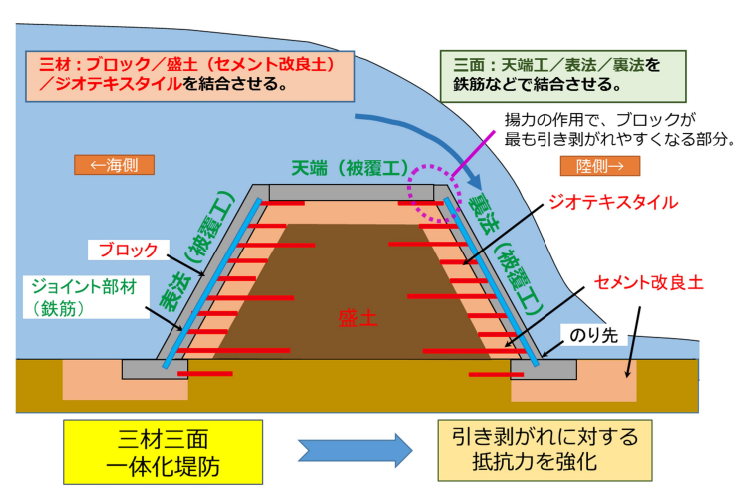

図-6 段波津波に対抗する堤防構造の提案 (三面一体化堤防)

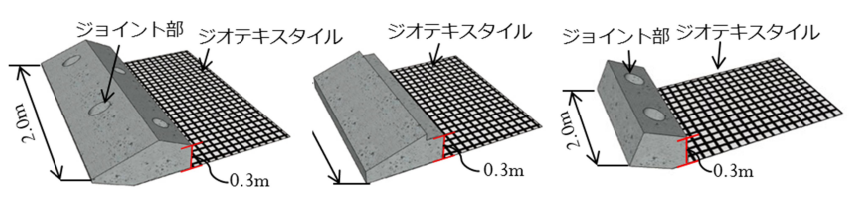

(a) GJブロック

(b) GSブロック

(c) SJブロック

図-7 ジオテキスタイルを連結したブロック

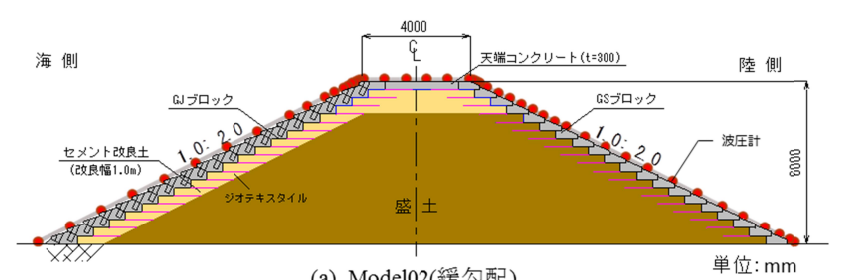

(a) Model02(緩勾配)

単位: $m m$

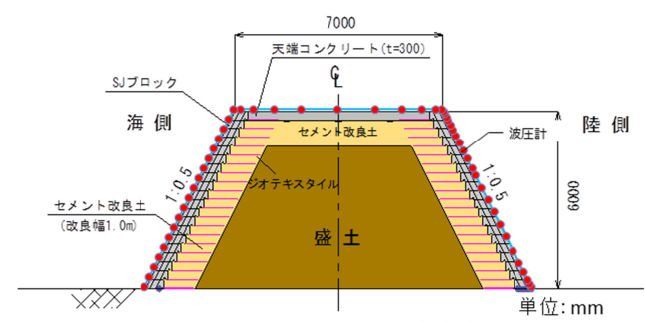

(b) Mode103\&Mode104(急勾配)

図-8 新型式堤防のモデル (Model02〜04)

メント添加量 (乾燥重量比) を光れ帒れ貧配合 $1.0 \%$ よ び富配合 $4.0 \%$ に設定し, 遮水性と固結力 (母材 : 鉾田砂) を高めた . ただし，貧配合のセメント改良土については， 水道水の流水で洗い出される程度の低いものであったた め，後述するように吸い出しか堹じた . なお，津波によ 
る浸透を考慮して飽和状態の供試体を用いた一軸圧縮強 度試験を実施した。光れ光れ貧配合で蚹 $=246 \mathrm{kN} / \mathrm{m}^{2}$, 富

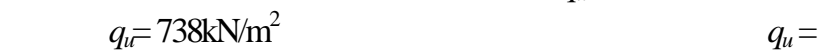
$3,690 \mathrm{kN} / \mathrm{m}^{2}, q_{u}=11,000 \mathrm{kN} / \mathrm{m}^{2}$ であり，圧縮強度としてはか なり大きめの值となった . 透水係数は富配合のセメント

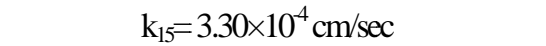

盛土材は鉾田砂 $\left(\mathrm{D}_{50}=0.103 \mathrm{~mm}, \mathrm{Fc}=33.9 \%, \mathrm{Uc}=26.0\right.$, $\left.\rho_{\mathrm{dmmx}}=1.669 \mathrm{~g} / \mathrm{cm}^{3}, \mathrm{k}_{15}=3.30 \times 10^{4} \mathrm{~cm} / \mathrm{sec}\right)$ であり，締固め度

(標準プロクター) でDc= 90\% , 厚さ $0.30 \mathrm{~m} / 15=2.0 \mathrm{cml}$ なるように転圧して構築した . 天端部は天端コンとジオ テキスタイルの付着力によって法肩ブロックと天端コン を連結させた . 表法側のブロックはジョイント材で上下 方向のブロックを連結した .

\section{(3) 入射条件の設定}

初期水位を海側の堤防法尻部での陸上面高さに設定 した条件に加えて, 津波到達により海水面が上昇した状 態で来襲する第2波，第3波の入射波を再現するため， 最大堤防高さの半分の高さまで水位が上昇した条件を設 定した . また，沖側の貯水位を段階的に引き上げて段波 の大きさを変化させた . 表-1に入射条件を示す .

表-1 入射条件 (現地換算)

\begin{tabular}{|c|c|c|c|c|}
\hline & $\begin{array}{c}\text { 初期水 } \\
\text { 位 }(\mathrm{m}) \\
\text { 貯水位 } \\
(\mathrm{m})\end{array}$ & $\begin{array}{l}\text { 進行波高 } \\
(\mathrm{m}) \\
\text { 砕波状態 } \\
\text { (回数) }\end{array}$ & $\begin{array}{c}\text { 最大波力 } \\
(\mathrm{kN} / \mathrm{m}) \\
\text { 最大越流 } \\
\text { 水深 }(\mathrm{m}) \\
\end{array}$ & 損傷状況 \\
\hline \multirow{5}{*}{ 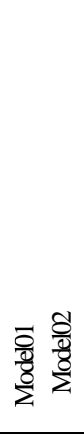 } & $\begin{array}{l}9.45 \\
17.7 \\
\end{array}$ & $\begin{array}{c}4.71 \\
\text { 直前砕波1回 } \\
\end{array}$ & $\begin{array}{l}1271 \\
3.93\end{array}$ & $\begin{array}{l}\text { Model01:栗石が懄に移動. } \\
\text { Model02:損傷無し. }\end{array}$ \\
\hline & $\begin{array}{l}9.45 \\
19.2\end{array}$ & $\begin{array}{c}4.49 \\
\text { 沖砕波1回 }\end{array}$ & $\begin{array}{l}1290 \\
3.06\end{array}$ & $\begin{array}{l}\text { Model01 : 裏法ブロックの一部か押 } \\
\text { し出された . Model02:損傷無し. }\end{array}$ \\
\hline & $\begin{array}{l}9.45 \\
22.2\end{array}$ & $\begin{array}{c}4.59 \\
\text { 沖砕波1回 }\end{array}$ & $\begin{array}{l}1452 \\
5.61\end{array}$ & $\begin{array}{l}\text { Model01:裏法ブロックの大半か押 } \\
\text { し出された . Mode102:損傷無し . }\end{array}$ \\
\hline & $\begin{array}{l}9.45 \\
24.5\end{array}$ & $\begin{array}{c}4.73 \\
\text { 沖砕波1回 }\end{array}$ & $\begin{array}{l}1506 \\
5.97\end{array}$ & $\begin{array}{l}\text { Model01:天端コンが浮き上がっ } \\
\text { た . Model02:損傷無し. }\end{array}$ \\
\hline & $\begin{array}{l}12.5 \\
25.2\end{array}$ & $\begin{array}{c}10.23 \\
\text { 沖砕波1回 }\end{array}$ & $\begin{array}{l}1483 \\
7.51\end{array}$ & $\begin{array}{l}\text { Mode101:表法ブロックの巻き上が } \\
\text { り, 天端コンが浮き上がった . } \\
\text { Model02:損傷無し . }\end{array}$ \\
\hline \multirow{3}{*}{ 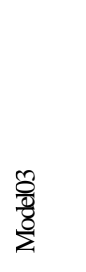 } & $\begin{array}{l}9.45 \\
15.2\end{array}$ & $\begin{array}{c}3.79 \\
\text { 直前砕波1回 }\end{array}$ & $\begin{array}{l}1185 \\
1.56\end{array}$ & $\begin{array}{l}\text { 表法ブロック背面のセメント改良 } \\
\text { 土か吸い出された . }\end{array}$ \\
\hline & $\begin{array}{l}9.45 \\
14.3\end{array}$ & $\begin{array}{c}3.24 \\
\text { 直前砕波1回 }\end{array}$ & $\begin{array}{l}437 \\
0.90\end{array}$ & $\begin{array}{l}\text { 表法ブロック背面に大きな空洞が } \\
\text { 発生した . }\end{array}$ \\
\hline & $\begin{array}{l}9.45 \\
15.8\end{array}$ & $\begin{array}{c}4.07 \\
\text { 直前砕波1回 }\end{array}$ & $\begin{array}{l}1949 \\
2.20\end{array}$ & $\begin{array}{l}\text { 空洞力昿大したため， } \\
\text { 実験を中止した . }\end{array}$ \\
\hline \multirow{3}{*}{ 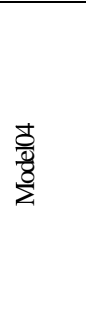 } & $\begin{array}{c}9.45 \\
14.7 \sim \\
24.4\end{array}$ & \begin{tabular}{|c|}
$3.08 \sim 6.57$ \\
砕波直前9回 \\
沖砕波13回 \\
\end{tabular} & $\begin{array}{l}320 \sim 8559 \\
0.57 \sim 7.02\end{array}$ & \multirow{2}{*}{$\begin{array}{l}\text { 天端コンが上向きに, 表法面か堤 } \\
\text { 防内側に徐々に変位した . セメン } \\
\text { ト改良土にクラックカ生じた . } \\
\text { 盛土材か徐々に吸い出され , ブロ } \\
\text { ック背面に空洞か発達した . }\end{array}$} \\
\hline & $\begin{array}{c}10.2 \\
15.1 \sim \\
25.17\end{array}$ & $\begin{array}{c}2.87 \sim 5.18 \\
\text { 非砕波5回 } \\
\text { 砕波直前5回 } \\
\text { 沖砕波5回 }\end{array}$ & $\begin{array}{l}607 \sim 4827 \\
0.78 \sim 6.96\end{array}$ & \\
\hline & $\begin{array}{l}10.2 \\
22.3 \\
\end{array}$ & $\begin{array}{c}4.35 \\
\text { 沖砕波1回 }\end{array}$ & $\begin{array}{r}731 \\
5.7 \\
\end{array}$ & 天端コンがめくれ上がった \\
\hline
\end{tabular}

（4）段波波力及ひ越流特性

直前砕波型の段波による表法面への作用波力及び前 浜波高の代表的な実験結果 (現地換算) を図-9に示す。
图-10には堤防中央部における越流水深，越流流速およ びフルード数の時刻歴を示す. 水谷·今村 (2000) 力報 告しているように，段波衝突時には図-9に示すように衝 撃的な波力が発生する. 兴の直後, 越波によって図10（）に示すように越流水深及び流速が急激に増加する . 兴の後, 沖側に向かう反射波力溌生し, 波力の著しい低 下と，越流水深及び流速の低下か堹じる．一方，前浜側 では反射波と入射波の連続的な到達によって著しい水位 上昇力㽓じる.この反射重複波力圷是防へ押し寄せる際に， 波力, 越流水深及び流速力再び上昇に転じる. 反射波の影響で上記の変動力漯り返される.やがて定常 的な゙流机に近づくと，越流水深及び流速の变動が小さく なり，表法面には持続的な波力が作用する．また，堤防 天端中央上ての越流水のフルード数は, 越波部分を除く

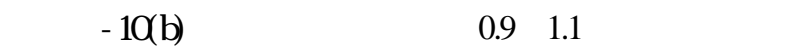
堤防天端上で常流から射流に変化していることがわかる. なお，非砕波型および䗋波型の段波は，直前砕波型と 異なり，衝突時に衝撃的波力は発生しないが, 衝突以降 の流況および波力に関する一連の变化は, 同樣な傾向を 示す.

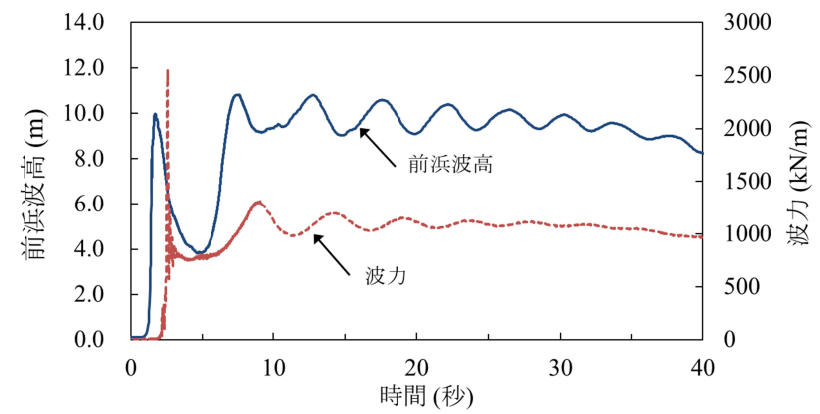

図-9 測線H1における前浜波高及び表法面 への作用波力の時刻歴 (現地換算)

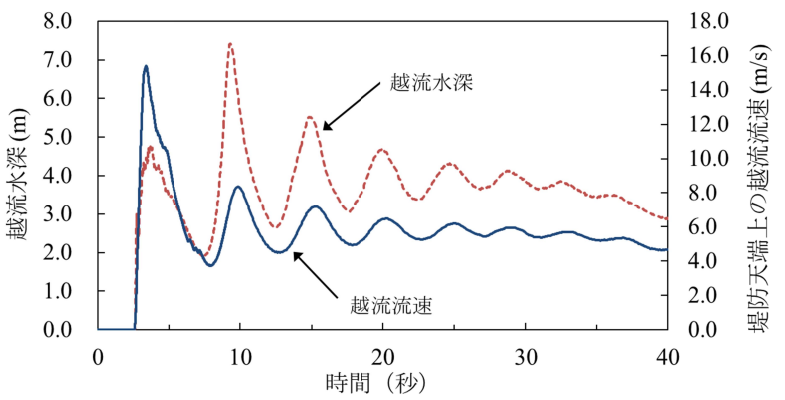

（a）越流水深及ひ越流流速の時刻歴 (現地換算)

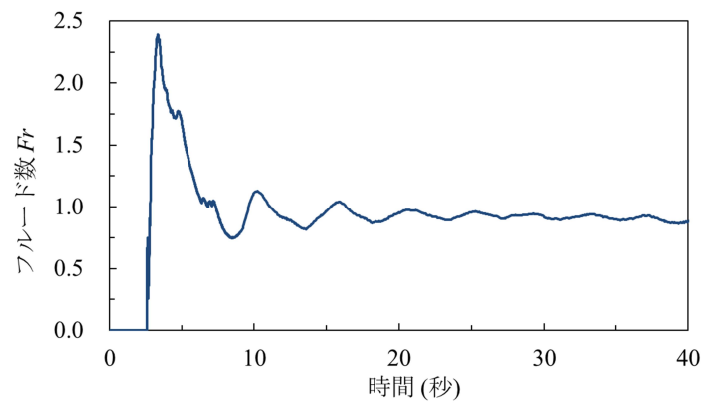

(b) 越流水のフルード数の時刻歴 (現地換算) 図-10 測線H2における堤防天端中央上での越流特性 


\section{3. 実験結果}

（1）従来式堤防モデル (Nodel O1) の損傷状況

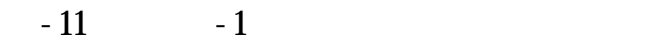
流流速と損傷の経時変化の関係 (現地換算) お よび損傷状況を示す．図-11(a)では，段波衝突 から 0.43 秒後に栗石か移動し, 裏法ブロックの 一部か押し出された . 炎の後, 写真-1(a)に示す ように連鎖的なブロックの流出に発展し，完全 な崩壊に至った . 図-11(b)では，段波衝突によ って表法面のブロックの一部が巻上げられた . その後, 写真1(b)に示すように天端コンが浮き 上がり，すべての裏法ブロックが一斉に流出し 約10.0秒後には完全崩壊した . 図-11(c)では，段 波衝突直後に表法ブロックが大きく巻上げられ た (写真-1(e) ) . そ後, 天端コン・裏法ブロ ックが流出し, 約7.0秒後に完全崩壊した . 図11(b)で示した実験における表法面への作用波力 と天端コン内外面に作用する波圧特性を図-12に 示す. 図-12 a) (現地換算值)に示すように， 表法面に波力が作用してから，0.2秒後に内外面 の波圧が同時に増加していた .

このことから , ブロック背面の栗石層には , 越流水とほほ同じ流速の浸透流力発生していた ものと考えられる.さらに , 図-12b) (現地換 算值) に示す天端コンの内外面の波圧差をみる と,一時的に外面よりも内面の方が, $15 \mathrm{kPa}$ 以上 も大きくなっている .この上向きの圧力は , 厚 み $0.50 \mathrm{~m} の$ 天端コンを押し上げるのに十分な大き さであり，天端コンが浮き上がる時刻にほぼ一 致していた .

\section{（2）新型式堤防モデルの損傷状況}

a)緩勾配タイプ (Nodel O2)

Model01と同じ段波津波を衝突させたが，堤防か破 堤に至るような損傷か苼じなかった . 以下に実験て観 測された状況を述べる．写真一にこ示すように津波衝突 時に発生する揚圧力に対して , 被覆ブロック同士を連 結したことによって表法ブロックの巻上げを完全に防 止できた . また , 難透水構造によって堤防内部一の津 波の浸入が遮断されて, 裏込め材の移動と被覆ブロッ クの流出を防止できた .さらに, 裏法肩付近に発生す る負圧に対しては, 法肩ブロックと天端コンは連結さ れているために引き绿がれに対して大きな抵抗モ一メ ントカが得られて , 法肩ブロックの引き录㸬れを完全 に防止することができた (松島ら，2014).

一方 , 写真-3に示すように , 裏法ブロック背面には 通常の盛土材を配置していたため, 盛土材か吸い出さ れて空洞が形成された .このためブロックが多少傾い たが , ジオテキスタイルによってブロックか固定され ていたため, ブロックは流出せず被覆構造は維持され て安定的に越流水を流下させることができた 。
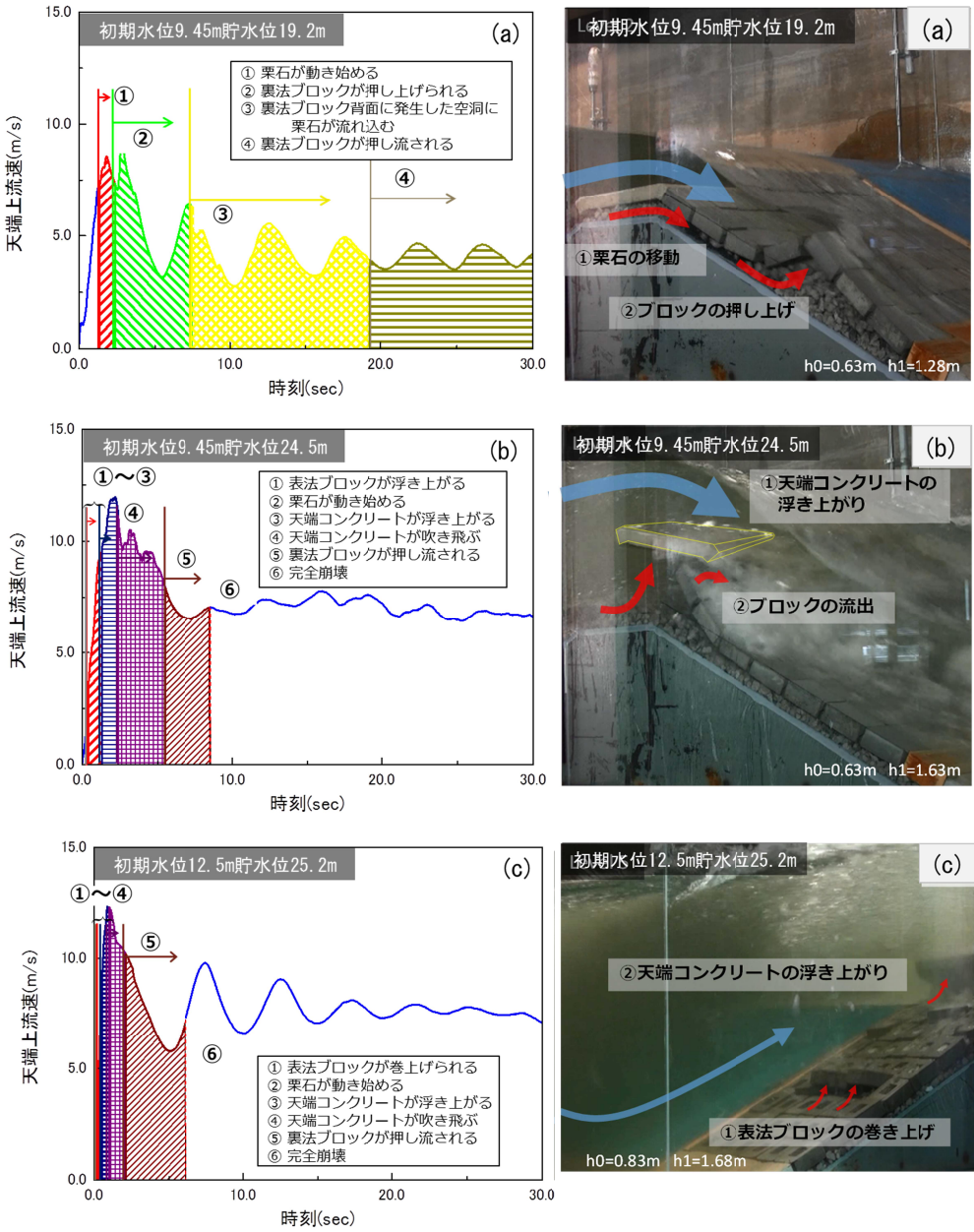

図-11 従来式堤防モデル(Model01) の損傷過程 (現地換算)

写真-1 従来式堤防モデル (Model01)の損傷状況

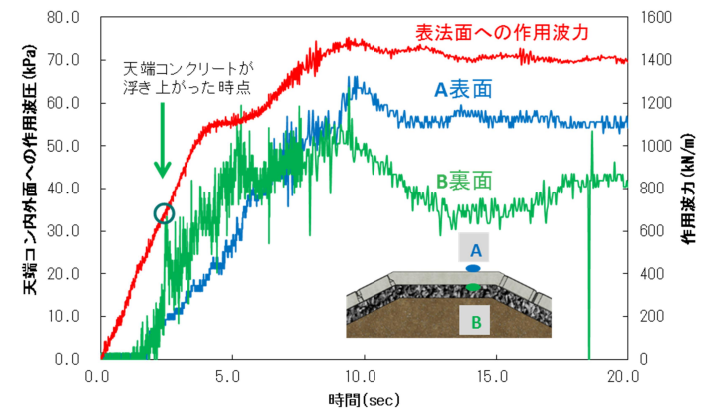

（a）表法面への波力と天端コン内外面の作用波圧

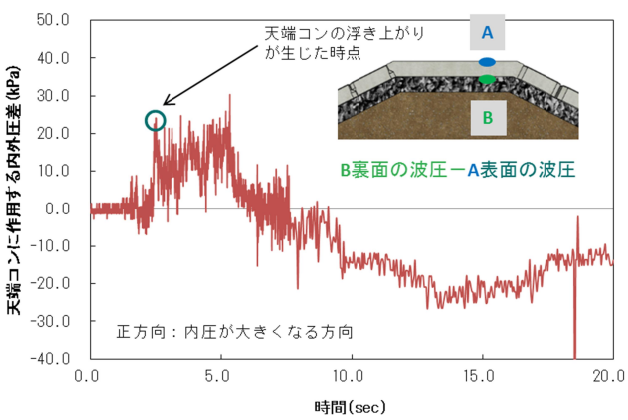

(b) 天端コン内外面の波圧差

図-12 Model01における天端コン内外面に作用する波圧特性 


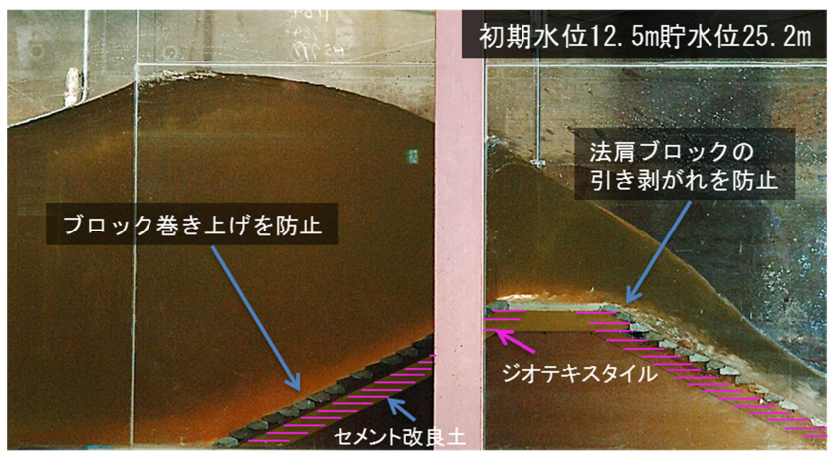

写真- 2 新型式堤防モデル(Model02)における表法の耐侵食性

b) 急勾配タイプ ( Nodel @〜O4)

Model03では, 貧配合のセメント改良土を用いたため に吸い出しか苼じたが, 計回の入射波でブロックの巻 き上げや引き录㔹れなどの損傷は生じなかった .これは Model02 と同樣に，難透水構造により堤防内部への津波 の浸入が遮断され, 裏込材の移動や被覆ブロックの流 出を防止できたためだと考えられる．ただし，写真-4 に示すように3波目の直前砕波の段波を作用させた時点 で天端コン背面や表法肩ブロック背面に大きな空洞か生 じた .このような゙状態になると，津波衝突時にブロック 背面の空隙に大きな水圧か作用して天端コンに大きな揚 圧力が作用してめくれ上がる可能性がある．弚のため， この段階で実験を中断した．

Model04では, 吸出し抵抗力を向上させるために富配 合のセメント改良土を用いた . 最初の非砕波の入射波で はまったく損傷は見られなかった．しかし，写真-5に示 すように波力が大きい直前砕波を作用させると，図-13 に示すように波力か強く作用する部位でブロックが盛土 側に変位して表法面は弓形に変形し , 陸側の上段ブロッ クか押し出された．これは，堤防内部に受働的な破壊が 生じたことを示している.衝撃的な荷重力継続する時間 は極めて短いため, 1度の段波で生じる変形量は僅かで あったが , 回数を重ねるごとに変形が大きくなった . 写 真- बは20回の段波を入射させた後の損傷状況である . ブ ロック間の隙間の拡大やジョイント部材の录漓隹 , さらに , ジオテキスタイル敷設面に沿ったセメント改良土のクラ ックか発生していることがかか .

上記の損傷が累積することによって盛土材の吸出し か湿著に生じるようになった . 最終的には沖砕波の段波 によって写真-7に示すように天端コンがめくれ上がった . 写真-8に示すように堤防が崩壊する以前の段階では同程 度以上の波に耐えていたが，段波を入射させる度に，(1) ブロック背面や天端コンの背面に空洞力発達して堤防の 水密性力徐々に喪失し, (2)空洞部分に津波力侵入して大 きな揚圧力か作用しやすくなった . その結果, 天端コン のめくれ上がりに発展したものと推察される .

以上から，次のことが分かった . (1)急勾配堤防では 水平方向に衝撃的な゙波力か作用するため, ジョイント部 材か変形・破断したり, ブロックの隙間か粧大したりす る可能性がある . (2) 損傷か蓄積されると盛土材か吸い 出され, 堤防の水密性が徐々に喪失して耐久性力低下す る.

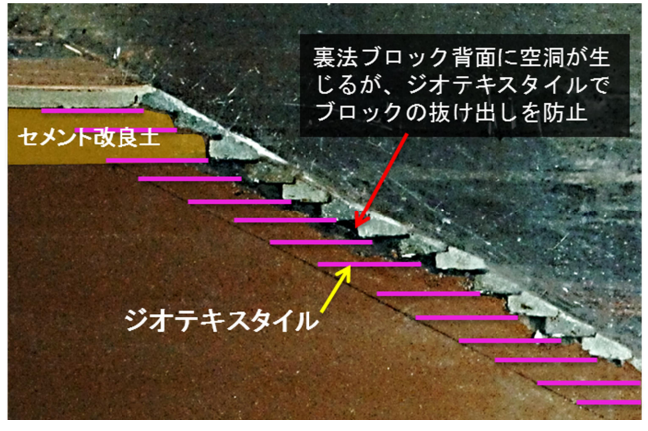

写真- 3 新型式堤防モデル (Model02) における裏法の耐侵食性

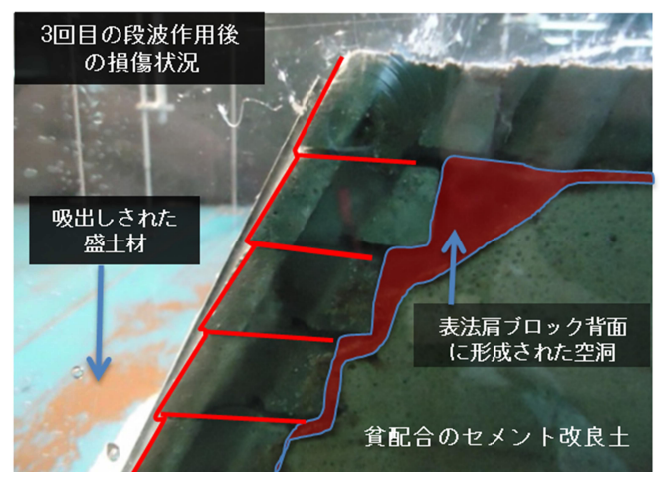

写真-4 新型式堤防モデル(Model03)における 表法肩ブロック背面の空洞

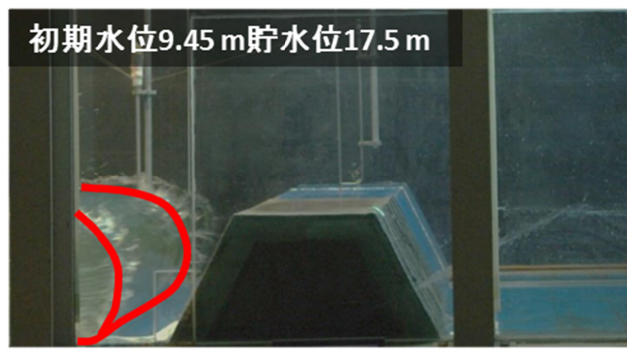

（a）段波衝突直前 (直前砕波型)

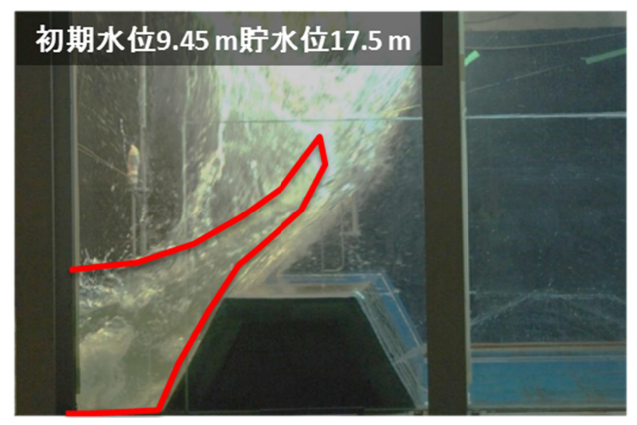

（b）段波衝突直後 (直前砕波型)

写真- 5 新型式堤防モデル(Model04) における直前砕波の衝突状況

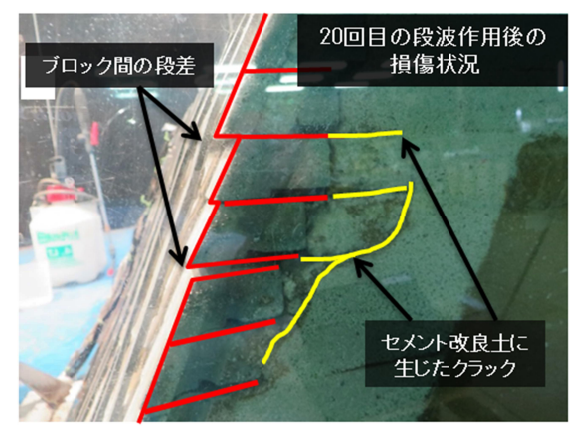

写真- 6 新型式堤防モデル(Model04)での損傷の累積 

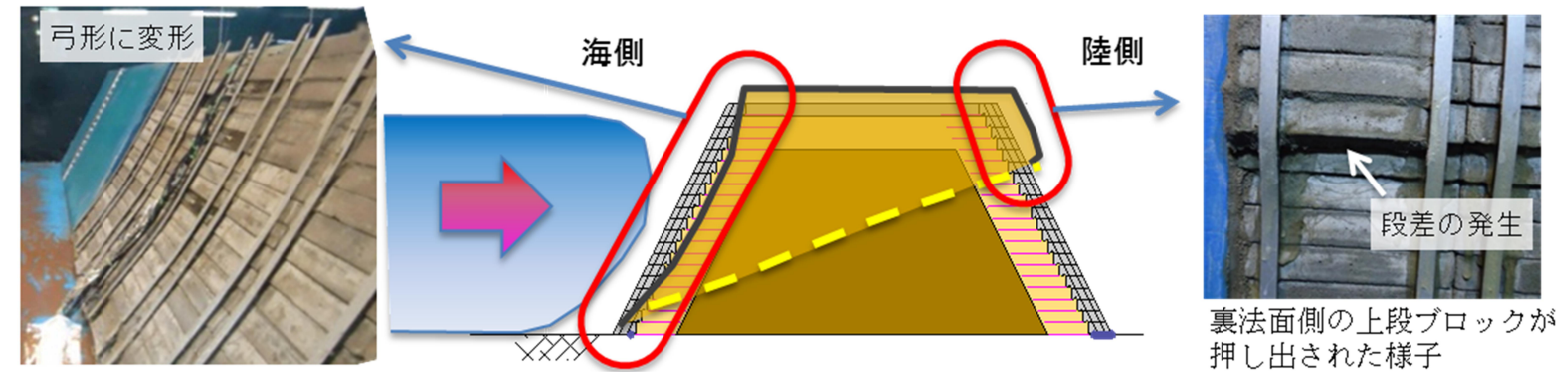

裏法面側の上段ブロックが 押し出された様子

図-12 衝撃的な゙波力 (直線砕波) による新型式堤防モデル(Model04)の損傷

\section{4 . 考察}

(1) 従来式堤防の構造的課題

従来の被覆ブロックを用いた堤防盛土は，(1)ブロッ ク重量によって波力に対抗し, (2)積極的に透水・透気構 造にすることによって揚圧力の低減を図っている．この ような構造は, 短周期の波浪に対しては有効である。し かし , 継続的に波力か作用する段波では, 表法ブロック の隙間を通じて栗石層に強い浸透流力発生するため, 栗 石層内の内圧上昇や栗石の移動によって裏法ブロックが 押し出される可能性がある.また，裏法肩付近に発生す る負圧に対して単体のブロックでは引き录师される虞が ある (国総研，2012a \&大井ら，2012)．また，段波衝 突時に表法側の被覆ブロック背面に津波か回り込み , 一 時的に揚圧力が作用する .ブロック自重よりも大きな揚 圧力が作用する場合には, ブロックか巻き上げられる可 能性力高まる。

\section{（2）効果的な対策}

上記の構造的課題の解決には，堤防内部一の津波の 浸入を遮断し, 堤防内部の水圧によってブロックか押し 出されない構造に改善することか効果的である . 具体的 には，(1)表法ブロックに遮水性を持たせる方法，あるい は(2)被覆ブロック背面を透水性の裏込め材から難透水性 の材料に変更する方法か学げられる . (1)としてはブロッ クの隙間をモルタル等て閉塞すればよいが , 長期的な盛 土の変形や基礎地盤の圧密による沈下, 高潮や地震時の 変形等か甡じると, 被覆ブロック間の隙間を完全に塞ぐ ことか困難になると想定される。したがって，(1)と(2)の 両者を採用して , ブロック間の嚐間をできるだけ少なく すると同時に，難透水性の裏込め材と一体化するの力洧 効であると考えられる .

一方, 津波の浸入を遮断した場合, 揚圧力や残留水 圧の消散か不十分になり，津波衝突時あるいは引き波時 にブロックの巻き上げ裏込め材か吸出される可能性か高 まる.このため, アンカー材によってブロックを盛土に 定着しブロック同士を連結させる方法等によって，揚圧 力に対する抵抗力を高める必要がある . また, 裏込め材 は固化処理等により粒子間の固結力を十分に確保し，流 動化や吸い出しに対する抵抗力を向上させる必要がある 堤防を急勾配化した場合については，水平方向に卓 越した波力か作用するため, 直前砕波時に現れる衝撃的 波力によって受働的な破壊が引き起こされる可能性があ

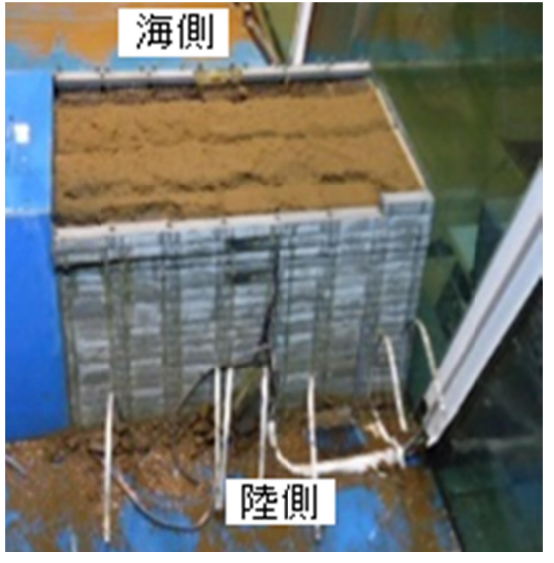

写真-7 天端コンがめくれ上がっだ状況 (Model04)

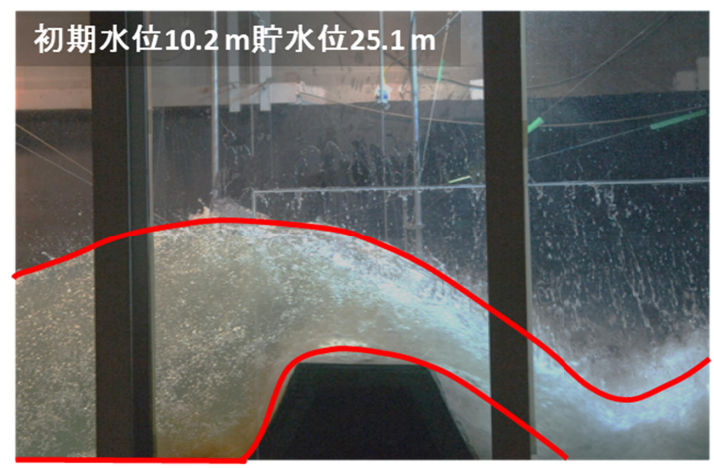

写真-8 沖砕波型の段波作用時の越流状況（Model04）

る.上記の衝撃的波力を設計でどの程度見込むのかは議 論の余地力残されるが , 堤防の損傷を軽減させるために は, ジョイント部材のせん断強度の向上, 堤防の断面積 の拡大 , 法面の緩勾配化などの対策が必要となる。

堤防越流時に作用する抗力や揚力に対しては，流水 に対する抵抗を増大させないように不陸の発生を抑制す る工夫 (国総研 , 2012b) や , ブロック同士の連結やジ オテキスタイルによる盛土への定着によって抗力や揚力 に対する抵抗力を向上させることか洧効である．

なお，上記の対策では，難透水性の裏込め材て堤防 を覆うため，堤防内の排気性が低下する．弚のため，国 総研(2012a)や小竹・磯部(2012) 力指摘しているように， 基礎地盤からの揚圧力によって堤防内の間隙空気圧が上 昇するとともに間隙空気の存在によって被覆工に大きな 浮力が作用することか懸念される .この揚圧力に対して は，被覆工とセメント改良土の一体化領域を拡大させて 重量て対抗させたり，同時に止水工を設けて基礎地盤か らの揚圧力の低减や遅延を図るなど，別途対策を検討し なければならない場合がある . 


\section{5 .まとめ}

本研究では, 被覆ブロック形式の防潮堤を対象とし て，堤防高さを上回る段波を再現した水理実験により， 従来式堤防の構造的課題と有効な対策法を実験的に検討 した．午の結果，従来式堤防は，段波作用時に透水性の 高い栗石層に津波が浸入し, 強い浸透流によって裏法ブ ロックや天端コンか押し出される可能性があることが分 かった . また，津波衝突時に生じる揚圧力によって表法 側のブロックを巻き上げられ，津波越流時に裏法肩付近 の負圧によってブロックを引き剥がされる可能性がある ことも分かった .

上記の構造的課題を解決するためには, 被覆ブロッ クのみならず堤防の内部構造を改善する必要があること

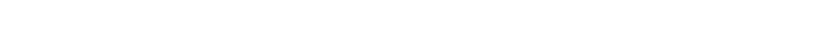
せることか洧効であることが分かった．(1)透水層を難透 水性のセメント改良土に置き換えて堤防内部一の津波の 浸入を遮断するとともに , 固結力により吸出し抵抗力を 確保する対策と，(2)負圧による被覆ブロックの引き剥が れ及ひ揚圧力による巻き上げに対して , ジオテキスタイ ルで盛土に定着させブロック同士を連結する対策である． 今後の課題として, 東日本大震災で発生した入射波 と実験条件との対応関係を明らかにし，本研究成果の適 用性を検討する必要がある。また，上記課題以外にも堤 体の耐震性 , 背後地盤の洗堀, 施工性・長期維持管理 性・コスト低减などの課題も検討を要する .

謝辞 : 本研究を進めるに当たり，国土交通省国土技術政 策総合研究所 加藤史訓博士から貴重な助言を頂きまし た 、ここに記して謝意を表します．また，農林水産省食 料生産地域再生のための先端技術展開事業「減災・防災 システムの開発・実証研究」および農研機構交付金課題 による補助を受けました．また，共同研究（技研興業 (株)， (公財) 鉄道総合技術研究所, 前田工繊（株）， 丸栄コンクリート (株) ) の関係者の協力を得ました 。

\section{参考文献}

1) 堀川清司(1991): 海岸工学, 東京大学出版会, pp.108-110.

2) (財) 国土開発技術研究センター (JCE) 編(1998) : 護岸の 力学設計法, 山海堂, pp.33-95.

3) 山口晋平 · 大林沙紀 ·川邊翔平 · 龍岡文夫 · 菊池善昭 ·二 瓶泰雄 : 津波に対する防潮堤補強技術に関する実験的検討， 国際ジオシンセティックス論文集，第28巻 , pp.245-250.

4) 常田賢一・竜田尚希 : 津波防潮のための“粘り強い”盛土 の補強構造，国際ジオシンセティックス論文集，第28巻， pp.259-264.

5) 山と土と樹を好きな漁師のホームページより引用， http://logs.yahoo.co.jp/sasaootako ，アクセス日2014年10月14日

6) 朝倉良介 · 岩瀬浩二 · 池谷毅 - 高尾誠 - 金戶俊道 $\cdot$ 藤井直 樹・大森政則(2000) : 護岸を越流した津波による波力に関す る実験的研究, 土木学会論文集B2 (海岸工学) , Vol. 47, No. 2, pp. I_911-_915.

7) 水谷将，今村文彦(2000): 構造物に作用する段波波力の実験， 海岸工学論文集, 第47巻, pp.946-950.

8) 松島健一 - 大井邦昭 - 毛利栄征 - 龍岡文夫 - 平井卓 $\cdot$ 桐博 英(2014) : 越流津波時の揚力による防潮堤法肩ブロックの引 き剥氿と光の対策，土木学会論文集B2 (海岸工学)，Vol. 70, 揭載中.

9) 国土交通省国土技術政策総合研究所河川研究部(2012a) : 粘り 強く効果を発揮する海岸堤防の構造検討(第2報), No. 3, 平成 24 年 8 月 10 日.

10) 大井邦昭・林建二郎・河野茂樹(2012) : 海岸越流に対する 海岸堤防及ひ防波堤の強化に関する実験的研究, 土木学会 論文集B3 (海洋開発) 特集号, Vol.68,No.2,pp.I96-I101.

11) 国土交通省国土技術政策総合研究所河川研究部(2012b)：粘 り強く効果を発揮する海岸堤防の構造檢討(第1報), №.1, 平成24年5月14日.

12) 小竹康夫・磯部雅彦(2012) : 津波の越流時に海岸堤防の法 面に作用する圧力特性に関する実験的研究, 土木学会論文 集B2 (海岸工学) ，Vol.68,No.2,pp. I_891-_895.

\title{
Development of Robust Coastal Dikes against Tsunami Bore
}

\section{Kenichi MATSUSHIMA, Yoshiyuki MOHRI, Kazunori OOGUSHI, Shohei KAWABE and Fumio TATSUOKA}

\begin{abstract}
Conventional type coastal dikes consisting of unreinforced backfill covered with concrete-blocks are designed to resist against wave forces by the self-weight of the concrete-blocks while dissipating the uplifting water pressure via a pervious layer underlying the blocks. However, continuous waves, like tsunami bore, generate dynamic positive wave pressure in the previous layer underlying the blocks that uplifts the blocks. In addition, the shoulder-blocks on the downstream slope are lifted up and dragged away by negative water pressure generated around the top of slope by overflowing tsunami current. In order to alleviate these structural defects, a new type coastal dike is proposed, which integrates concrete-blocks using geotextile to an underlying low-permeable soil-cement layer. The results of hydraulic model tests indicate that the new type dike has a high stability against tsunami bore by restraining the generation of dynamic positive wave pressure inside the backfill, while resisting against uplift force by anchoring the concrete -blocks with geotextile to stable backfill and connecting each other via a joint structure.
\end{abstract}

KEYWORDS: Tsunami bore, Coastal dike, Geotextile, Precast concrete block, Cement treated soil 